\title{
Manipulating nutrient composition of microalgal growth media to improve biomass yield and lipid content of Micractinium pusillum
}

\author{
Reda A.I. Abou-Shanab ${ }^{1,2}$, Sapireddy V. Raghavulu' ${ }^{1}$, Nagah M.A. Hassanin², Seongheon Kim", \\ Yong Je Kim³, Sang Un Oh${ }^{4}$, You-Kwan $\mathrm{Oh}^{5}$, and Byong-Hun Jeon ${ }^{1 *}$ \\ ${ }^{1}$ Department of Environmental Engineering, Yonsei University, Wonju, Gangwon-do 220-710, South Korea. \\ ${ }^{2}$ City of Scientific Research and Technology Applications, New Borg El Arab City, Alexandria 21934, Egypt. \\ ${ }^{3}$ Geologic Environment Division, KIGAM, Daejeon 305-350, South Korea. \\ ${ }^{4}$ Department of Biological Environment, Kangwon National University, Chuncheonsi, Gangwon-do, South Korea. \\ ${ }^{5}$ Korea Institute of Energy Research, Daejeon 305-343, South Korea.
}

Accepted 9 November, 2012

Biodiesel production from microalgae depends on the algal biomass and lipid content. Both biomass production and lipid accumulation are limited by several factors in which nutrients play a key role. We investigated the influences of micronutrients on biomass, and lipid content of Micractinium pusillum GU732425 cultivated in bold basal media (BBM). The average dry biomass of microalgal strain in control medium reached $0.34 \pm 0.01 \mathrm{~g} / \mathrm{L}$, while doubling $(2 \mathrm{X})$ the levels of $\mathrm{Mn}$ and $\mathrm{Cu}$ concentration increased the dry biomass to $0.38 \pm 0.01$ and $0.37 \pm 0.02 \mathrm{~g} / \mathrm{L}$, respectively. M. pusillum cultivated in control medium had a biomass of $0.82 \pm 0.05 \mathrm{~g} / \mathrm{L}$ and a lipid productivity of $0.33 \pm 0.02 \mathrm{~g} / \mathrm{L}$ after 17 day cultivation. The alga cultivated in BBM with $4 X$ Mn or $4 X$ Cu produced more biomass (1.25 \pm 0.01 or 1.28 $\pm 0.04 \mathrm{~g} \mathrm{dw} / \mathrm{L})$ and lipid productivity $(0.45 \pm 0.04$ or $0.47 \pm 0.05 \mathrm{~g} / \mathrm{L})$, respectively. $M$. pusillum cultivated in different growth media had fatty acid compositions mainly comprising linoleic (49-54\%), palmitic (24$29 \%$ ), linolenic (16-22\%), and oleic acids (2-5\%). These results can be used to maximize the production of microalgal biomass and lipids in optimally designed photobioreactors.

Key words: Micractinium pusillum, biomass, lipid production, media composition, fatty acids, trace metals.

\section{INTRODUCTION}

Both rapid growth and industrialization of nations have resulted in a steep increase in the production and consumption of fossil fuels. This increase has not only put severe stress on already depleting fossil fuels, but also resulted in an alarming increase in pollution across the globe. The current demand for biofuel as a gasoline substitute is extremely high due to the high cost of petroleum or the potential for a high cost. One such fuel showing great potential is biodiesel that has received much attention recently, as it is made from non-toxic, biodegradable, and renewable resources. Biodiesel also has environmental benefits, because they have fewer

*Corresponding author. E-mail: bhjeon@yonsei.ac.kr. Tel: +82 33760 2446. Fax: +82 337602571. harmful emissions, such as carbon monoxide and hydrocarbons, and can decrease the greenhouse effect (Gouveia and Oliverira, 2009; Campbell et al., 2011).

Microalgae are emerging as one of the most promising resources of biodiesel with a projected yield of 58,700 to 136,900 L/ha/year (Chisti, 2007). Microalgae have a number of advantages as a potential feedstock to produce biodiesel, including higher photosynthetic efficiency, biomass production, and growth rates than other energy crops (Huang et al., 2010). Many microalgae have the ability to produce substantial amounts ( 1 to $70 \%$ dry cell weight) of triacylglycerols (TAG) as a storage lipid under photo-oxidative stress or other adverse environmental conditions (Richmond, 2004; Cheirsilp and Torpee, 2012). Lipid production from microalgae can be improved by manipulating growth conditions such as nitrogen deprivation (IIIman et al., 
2000), silicon deficiency (Lynn et al., 2000), phosphate limitation (Reitan et al., 1994), high salinity (Rao et al., 2007), and some heavy metal stress (Guschina and Harwood, 2006).

The nutritional attributes of microalgae depend upon several intrinsic factors, such as their biochemical composition, average size, cell wall digestibility, and lipid accumulation. Dunaliella tertiolecta required inorganic phosphates and trace elements (that is $\mathrm{Co}, \mathrm{Mo}, \mathrm{Fe}$, and $\mathrm{Mn}$ ) to be grown optimally (Chen et al., 2011). Although several studies of individual nutrients such as carbon (Hosoglu et al., 2012), nitrogen (Shen et al., 2009), and iron (Liu et al., 2008) have been published, the effect of micronutrient concentration on algal growth and lipid production has not been reported.

Therefore, our study evaluated the effects of micronutrients (that is $\mathrm{Zn}, \mathrm{Mn}, \mathrm{Cu}$, and $\mathrm{Co}$ ) on biomass production and lipid content of $M$. pusillum. Furthermore, we investigated the fatty acid composition of this microalgal strain.

\section{MATERIALS AND METHODS}

\section{Algal strain and medium preparation}

M. pusillum GU732425 used in this study was isolated from the effluent of a municipal wastewater treatment plant in Wonju, South Korea (Abou-Shanab et al., 2011). The alga was cultivated in Bold Basal Medium (BBM) (Bischoff and Bold, 1963) containing $\mathrm{KH}_{2} \mathrm{PO}_{4}$ (175 mg/L), $\mathrm{CaCl}_{2} \cdot 2 \mathrm{H}_{2} \mathrm{O}(25 \mathrm{mg} / \mathrm{L}), \mathrm{MgSO}_{4} \cdot 7 \mathrm{H}_{2} \mathrm{O}(75 \mathrm{mg} / \mathrm{L}), \mathrm{NaNO}_{3}$ (250 mg/L), $\mathrm{K}_{2} \mathrm{HPO}_{4}(75 \mathrm{mg} / \mathrm{L}), \mathrm{NaCl}(25 \mathrm{~g} / \mathrm{L}), \mathrm{H}_{3} \mathrm{BO}_{3}(11.42 \mathrm{mg} / \mathrm{L})$, trace metal solution $(1 \mathrm{~mL} / \mathrm{L})$ consisting of $\mathrm{ZnSO}_{4} \cdot 7 \mathrm{H}_{2} \mathrm{O}(8.82 \mathrm{~g} / \mathrm{L})$, $\mathrm{MnCl}_{2} \cdot 4 \mathrm{H}_{2} \mathrm{O}(1.44 \mathrm{~g} / \mathrm{L}), \mathrm{MoO}_{3}(0.71 \mathrm{~g} / \mathrm{L}), \mathrm{CuSO}_{4} \cdot 5 \mathrm{H}_{2} \mathrm{O}(1.57 \mathrm{~g} / \mathrm{L})$, and $\mathrm{Co}\left(\mathrm{NO}_{3}\right)_{2} \cdot 6 \mathrm{H}_{2} \mathrm{O}(0.49 \mathrm{~g} / \mathrm{L})$, alkaline EDTA stock solution (1 $\mathrm{mL} / \mathrm{L})$ consisting of $\mathrm{Na}_{2} \mathrm{EDTA}(50 \mathrm{~g} / \mathrm{L})$ and $\mathrm{KOH}(31 \mathrm{~g} / \mathrm{L})$, and acidified iron stock solution (1 mL/L) consisting of $\mathrm{FeSO}_{4}(4.98 \mathrm{~g} / \mathrm{L})$ and $\mathrm{H}_{2} \mathrm{SO}_{4}(1 \mathrm{~mL})$. Regular BBM was amended with different concentrations of zinc (8.82 and $17.64 \mathrm{~g} / \mathrm{L})$ as $\mathrm{ZnSO}_{4} \cdot 7 \mathrm{H}_{2} \mathrm{O}$, manganese $(1.44,2.88,4.32,5.76,7.20$, and $8.64 \mathrm{~g} / \mathrm{L})$ as $\mathrm{MnCl}_{2} \cdot 4 \mathrm{H}_{2} \mathrm{O}$, copper $(1.57,3.14,4.71,6.28,7.58$, and $9.42 \mathrm{~g} / \mathrm{L})$ as $\mathrm{CuSO}_{4} \cdot 5 \mathrm{H}_{2} \mathrm{O}$, or cobalt $(0.49$ and $0.98 \mathrm{~g} / \mathrm{L})$ as $\mathrm{Co}\left(\mathrm{NO}_{3}\right)_{2} \cdot 6 \mathrm{H}_{2} \mathrm{O}$. The amended concentration of each nutrient was expressed as a fold change toward the concentration in regular BBM (control). Separate tests were conducted using micronutrient-depleted media, to evaluate the growth and biochemical properties of $M$. pusillum cultivated in growth media lacking a particular nutrient. The $\mathrm{pH}$ of the media used in this study was adjusted to 6.6 before autoclaving at $121^{\circ} \mathrm{C}$ for $15 \mathrm{~min}$.

\section{Microalgal cultivation and growth analysis}

Liquid medium [100 $\mathrm{mL}$ at $10 \%(\mathrm{v} / \mathrm{v})$ ] was inoculated with the algal strain in $250 \mathrm{~mL}$ Erlenmeyer flasks. The flasks were incubated under continuous white fluorescent light at $40 \mu \mathrm{mol}$ photon $/ \mathrm{m}^{2} / \mathrm{s}$ at $27 \pm 2^{\circ} \mathrm{C}$ for 17 days, while shaking at $150 \mathrm{rpm}$ on a rotary shaker (SH-804, Seyoung Scientific). Algal growth was measured by determining the optical density of the algal cell suspension at 680 $\mathrm{nm}$ using a DR/4000 v spectrophotometer ( $\mathrm{HACH}, \mathrm{USA})$. The $\mathrm{OD}_{680}$ was then converted to dry weight concentration using a linear relationship between $\mathrm{OD}_{680}$ and dry cell weight $(\mathrm{g} / \mathrm{L}$ ) (American Public Health Association, 1998), which was obtained after an extensive data analysis in this study. Experiments were carried out in triplicate, and data are expressed as mean \pm standard deviation.

\section{Lipid extraction and fatty acid analyses}

The total lipids were extracted from $M$. pusillum biomass $(0.2 \mathrm{~g} / \mathrm{L})$ using a slightly modified method of Bligh and Dyer (1959). In brief, cells were harvested and lyophilized. Lipids were extracted with a mixture of chloroform and methanol $(1: 2, v / v)$, transferred into a glass tube, and indirectly sonicated for $30 \mathrm{~min}$ at a constant frequency of $40 \mathrm{kHz}$ and at a power output of $700 \mathrm{~W}$ using a Powersonic 420 bath sonicator, South Korea. The tube was then incubated over night at $27^{\circ} \mathrm{C}$ with shaking at $100 \mathrm{rpm}$. An additional aliquot of chloroform $(1.25 \mathrm{~mL})$ was added to the tube and the content was sonicated again for $30 \mathrm{~min}$. To separate the chloroform and aqueous methanol layers, $1.25 \mathrm{~mL}$ deionized water was added to the tube, which was then centrifuged at $4000 \mathrm{rpm}$ for $10 \mathrm{~min}$. The chloroform layer was collected from the bottom of the tube. A second extraction was performed by adding $2.5 \mathrm{~mL}$ chloroform and vortexing. The chloroform layer was gently collected from the bottom of the tube, washed with $5 \mathrm{~mL}$ of $5 \% \mathrm{NaCl}$ solution, and evaporated in a dry oven at $50^{\circ} \mathrm{C}$. The percent lipid of total dry biomass was calculated as weight of crude lipids that was used for fatty acid methyl ester analysis. Each experiment was carried out in triplicate and average values were reported.

Fatty acids were analyzed using a modification of the method proposed by Lepage and Roy (1984). The crude lipid ( $10 \mathrm{mg}$ ) was dissolved in $2 \mathrm{~mL}$ of a freshly prepared chloroform and methanol mixture $(2: 1, v / v)$ and transferred to a $10 \mathrm{~mL}$ Pyrex tube with a Teflon-sealed screw-cap. $1 \mathrm{~mL}$ of chloroform containing an internal standard and transmethylation reagents was added to the tube and mixed for $5 \mathrm{~min}$. The contents were transferred to a $10 \mathrm{~mL}$ Pyrex tube, incubated at $100^{\circ} \mathrm{C}$ for $10 \mathrm{~min}$, cooled to room temperature, and separated into two phases by adding $1 \mathrm{~mL}$ deionized water. After 10 min of vigorous mixing and centrifugation at $4000 \mathrm{rpm}$ for another $10 \mathrm{~min}$, the chloroform layer was collected from the bottom of the tube using a hypodermic disposable polypropylene syringe and filtered through $0.2 \mu \mathrm{m}$ syringe filters. Fatty acid methyl esters (FAMEs) in the extracted liquid were quantified by QP2010 Gas Chromatography-Mass Spectrometry (Shimadzu, Japan) with a flame ionization detector using a HP-5MS capillary column.

The oven temperature was set at $80^{\circ} \mathrm{C}$, held for $5 \mathrm{~min}$, raised to $290^{\circ} \mathrm{C}$ at $4^{\circ} \mathrm{C} / \mathrm{min}$, and held at $290^{\circ} \mathrm{C}$ for $5 \mathrm{~min}$, and the temperature for injector and detector were set at 250 and $230^{\circ} \mathrm{C}$, respectively. Helium was used as a carrier gas at a flow rate of $1.2 \mathrm{~mL} / \mathrm{min}$. The compounds were identified by comparing fragmentation patterns with those in the National Institute of Standards and Technology (NIST) library.

\section{Statistical analysis}

All data are represented as mean \pm standard deviation of triplicate. Statistical analysis was performed using the SPSS package system version 11.

\section{RESULTS AND DISCUSSION}

\section{Effect of media compositions on the growth rate of $M$. pusillum}

Microalgae can grow profusely when supplied with sufficient nutrients under suitable conditions. Algal growth is directly affected by light and nutrient availability, $\mathrm{pH}$ and temperature stability, and the initial density of 

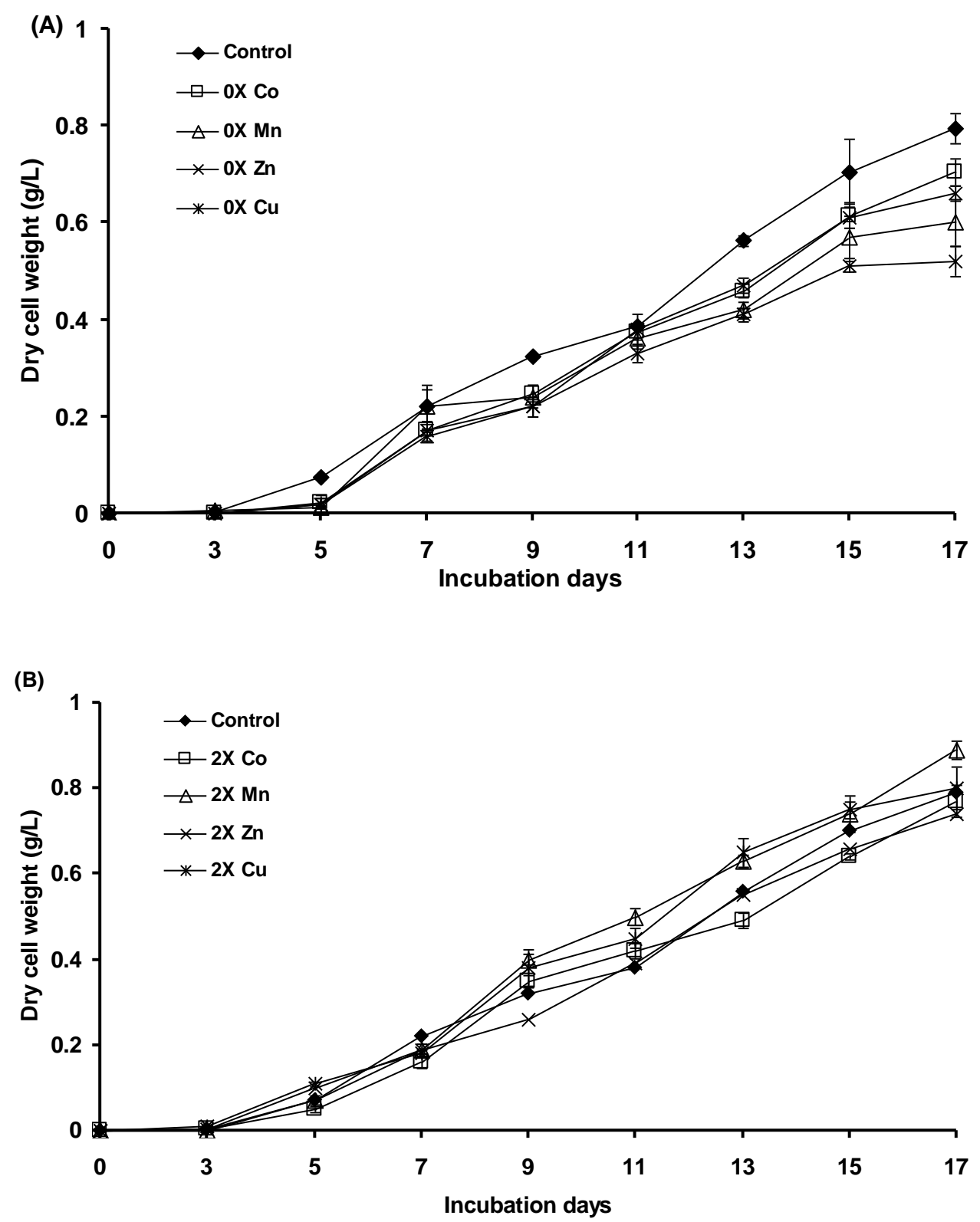

Figure 1. Dry cell weight of $M$. pusillum grown in (A) micronutrient-depleted media (OX) and (B) media containing a double each trace metal $(2 X)$.

inoculum (Wang et al., 2010a). A certain amount of trace metals (that is $\mathrm{Mn}, \mathrm{Cu}, \mathrm{Zn}$, and $\mathrm{Co}$ ) is capable to induce the growth of microalgae, while at the same time higher concentrations of these micronutrients can retard the growth of microalgae (llavarasi et al., 2011). Figure 1A shows that depleting individual micronutrients (that is Co, $\mathrm{Mn}, \mathrm{Zn}$, and $\mathrm{Cu}$ ) from the culture media significantly decreased the M. pusillum growth rate compared with the control (paired $t$-test $=3.42, P<0.01$ ). The average dry biomass concentration of $M$. pusillum grown in BBM (control) was $0.34 \pm 0.01 \mathrm{~g} / \mathrm{L}$, while for micronutrientdepleted BBM, the dry biomass ranged from $0.24 \pm 0.01$ $\mathrm{g} / \mathrm{L}(0 X \mathrm{Cu})$ to $0.28 \pm 0.01 \mathrm{~g} / \mathrm{L}(0 \times \mathrm{Co})$ after 17 day of cultivation. Micronutrients (Co, $\mathrm{Mn}, \mathrm{Zn}$, and $\mathrm{Cu}$ ) are essential for microalgal growth. These elements play vital roles in the active site of many algal enzymes and are involved in numerous metabolic processes, including photosynthesis and energy storage (Christensen, 1997; Liu et al., 2008; Chen et al., 2011). Thus, depleting micronutrients from the culture medium adversely affected $M$. pusillum growth.

The average dry biomass of $M$. pusillum increased with the increase of $\mathrm{Mn}$ or $\mathrm{Cu}$ concentrations (from 2X to $4 \mathrm{X}$ ) in the growth medium (Figure 1B). The dry biomass concentration of microalgal strain in BBM supplemented with double concentration (2X) of $\mathrm{Mn}$ or Cu reached 0.38 


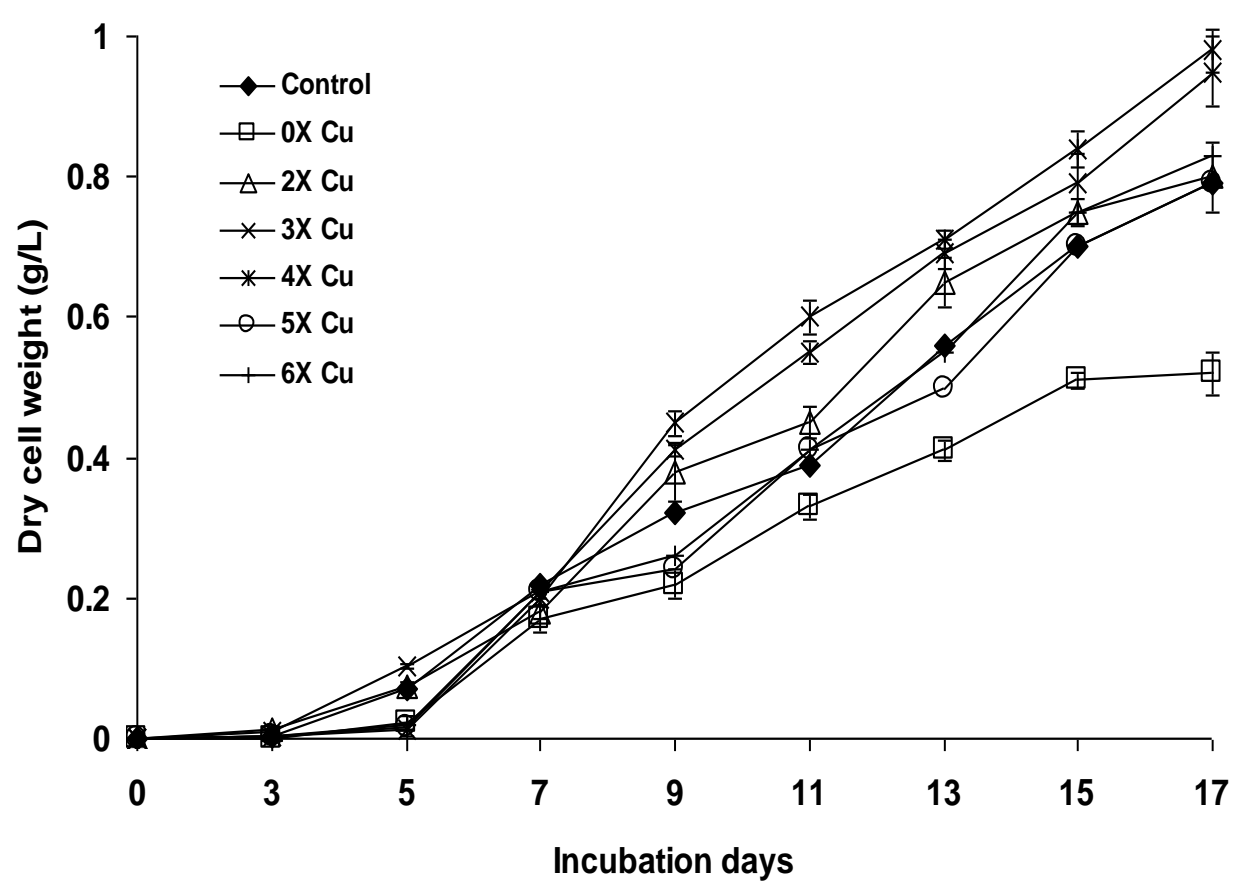

Figure 2. Dry cell weight of $M$. pusillum grown in BBM with different copper concentrations compared with control.

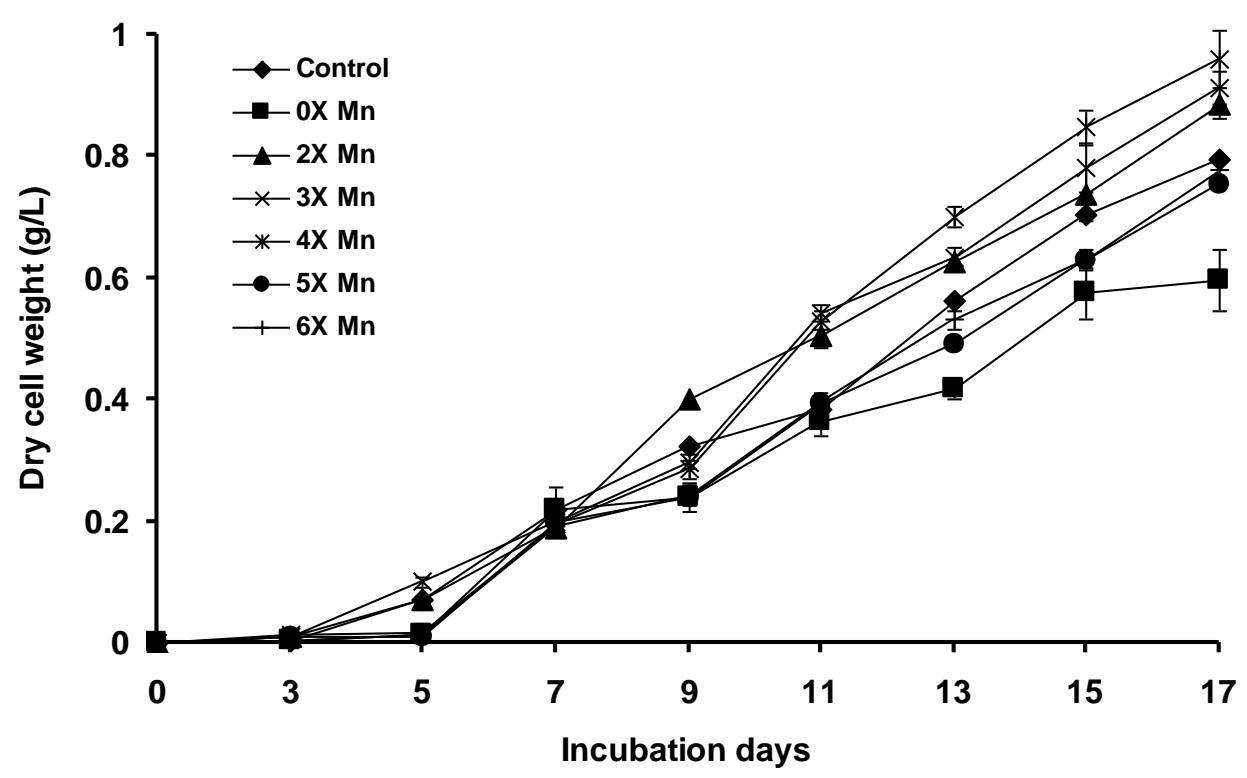

Figure 3. Dry cell weight of $M$. pusillum grown in BBM with different manganese concentrations compared with control.

$\pm 0.01 \mathrm{~g} / \mathrm{L}$ or $0.37 \pm 0.02 \mathrm{~g} / \mathrm{L}$, respectively, after 17 days of incubation, both of which were significantly higher (paired $t$-test $-2.3, P<0.05)$ than the control $(0.34 \pm$ $0.01)$. In contrast, increasing the $\mathrm{Zn}$ or Co concentration in the growth media had no noticeable effect on dry weight. Based on these results, further experiments evaluated $M$. pusillum growth as a function of $\mathrm{Mn}$ or $\mathrm{Cu}$ concentration in BBM. Increasing the $\mathrm{Mn}$ or $\mathrm{Cu}$ concentration to $4 \mathrm{X}$, increased the $M$. pusillum biomass $(0.39 \pm 0.01$ or $0.42 \pm 0.01 \mathrm{~g} / \mathrm{L}$, respectively) compared to regular BBM (Figures 2 and 3). Interestingly, increasing the $\mathrm{Mn}$ or $\mathrm{Cu}$ concentration to $5 \mathrm{X}$ or higher had no further 
Table 1. Effect of trace metals concentration in the growth medium on biomass yield, lipid production, and lipid content of $M$. pusillum

\begin{tabular}{|c|c|c|c|c|c|c|c|c|c|c|c|}
\hline \multirow{2}{*}{ Parameter } & \multirow{2}{*}{ Control } & \multicolumn{2}{|c|}{ Zinc } & \multicolumn{2}{|c|}{ Cobalt } & \multicolumn{6}{|c|}{ Manganese } \\
\hline & & $0 X$ & $2 X$ & $0 X$ & $2 X$ & $0 X$ & $2 X$ & $3 x$ & $4 X$ & $5 X$ & $6 X$ \\
\hline Biomass (g dw/L) & $0.82 \pm 0.05$ & $0.69 \pm 0.12$ & $0.76 \pm 0.04$ & $0.71 \pm 0.12$ & $0.85 \pm 0.09$ & $0.61 \pm 0.12$ & $1 \pm 0.08$ & $1.20 \pm 0.04$ & $1.25 \pm 0.01$ & $0.98 \pm 0.09$ & $0.99 \pm 0.03$ \\
\hline Lipid productivity (g/L) & $0.33 \pm 0.02$ & $0.26 \pm 0.01$ & $0.30 \pm 0.02$ & $0.24 \pm 0.02$ & $0.28 \pm 0.01$ & $0.23 \pm 0.01$ & $0.41 \pm 0.02$ & $0.40 \pm 0.02$ & $0.45 \pm 0.04$ & $0.39 \pm 0.05$ & $0.38 \pm 0.04$ \\
\hline Lipid content (\%) & $40 \pm 3.1$ & $38 \pm 2.5$ & $39 \pm 3.5$ & $34 \pm 0.5$ & $33 \pm 5.9$ & $38 \pm 2.9$ & $41 \pm 1.5$ & $33 \pm 1.8$ & $36 \pm 3.1$ & $40 \pm 1.5$ & $38 \pm 3.4$ \\
\hline \multirow{2}{*}{ Parameter } & \multirow{2}{*}{ Control } & \multicolumn{10}{|c|}{ Copper } \\
\hline & & \multicolumn{2}{|c|}{$0 X$} & \multicolumn{2}{|l|}{$2 X$} & $3 X$ & \multicolumn{2}{|c|}{$4 X$} & $5 X$ & \multicolumn{2}{|r|}{$6 X$} \\
\hline Biomass (g dw/L) & $0.82 \pm 0.05$ & \multicolumn{2}{|c|}{$0.60 \pm 0.04$} & \multicolumn{2}{|c|}{$1.04 \pm 0.16$} & $1.21 \pm 0.12$ & \multicolumn{2}{|c|}{$1.28 \pm 0.04$} & $1.19 \pm 0.09$ & \multicolumn{2}{|c|}{$0.99 \pm 0.01$} \\
\hline Lipid productivity (g/L) & $0.33 \pm 0.02$ & \multicolumn{2}{|c|}{$0.24 \pm 0.04$} & \multicolumn{2}{|c|}{$0.39 \pm 0.16$} & $0.45 \pm 0.02$ & \multicolumn{2}{|c|}{$0.47 \pm 0.05$} & $0.35 \pm 0.02$ & \multicolumn{2}{|c|}{$0.31 \pm 0.02$} \\
\hline Lipid content (\%) & $40 \pm 3.1$ & \multicolumn{2}{|c|}{$40 \pm 1.9$} & \multicolumn{2}{|c|}{$38 \pm 0.5$} & $37 \pm 3.7$ & \multicolumn{2}{|c|}{$38 \pm 1.5$} & $32 \pm 1.1$ & \multicolumn{2}{|r|}{$31 \pm 3.5$} \\
\hline
\end{tabular}

effect on the algal biomass concentration. These results reveal that a 4 -fold increase in $\mathrm{Mn}$ or $\mathrm{Cu}$ concentration maximized the $M$. pusillum dry biomass. Our result was consistent with earlier reports showing that $\mathrm{Mn}$ had stronger impact on the growth of Ulothrix sp. (Rousch and Sommerfeld, 1999).

\section{Biomass yield and lipid productivity}

We harvested the algal cells after the 17 day incubation and examined lipid content, lipid productivity and biomass yield (Table 1). Depleting $\mathrm{Zn}, \mathrm{Mn}$, Co, or Cu from growth medium adversely affected algal biomass and lipid production. M. pusillum grown in BBM with $4 \mathrm{X} \mathrm{Cu}$ or $\mathrm{Mn}$ produced more biomass $(1.28 \pm 0.04$ or $1.25 \pm 0.01 \mathrm{~g} / \mathrm{L})$ and lipid productivity $(0.47 \pm 0.05$ or $0.45 \pm 0.04 \mathrm{~g} / \mathrm{L})$ after 17 day of cultivation than the control (Table 1). Increasing the $\mathrm{Mn}$ or $\mathrm{Cu}$ concentration to $5 \mathrm{X}$ or higher had no further effect on the alga dry weight. This finding was consistent with the result of Wang et al. (2010b) who found that the increase of $\mathrm{Mn}$ concentrations stimulated the growth of blue green algae, while a further increase in $\mathrm{Mn}$ inhibited algal growth. The total lipid contents of $M$. pusillum in this study ranged from $31 \pm 3.5 \%$ to $41 \pm 1.5 \%$ of the dry biomass weight.

The highest lipid content $(41 \pm 1.5 \%)$ was presented by the algal strain grown in BBM containing 2X Mn. Cloe"z et al. (1987) found that lipid synthesis increased by three times after adding manganese, copper, and nickel at $2 \mathrm{mM}$. Hydrocarbon production was more sensitive to the change in $\mathrm{Mn}$ concentration. An increase in hydrocarbon production resulted from the increase of Mn concentrations (Song et al., 2012). Many microalgae species can be induced to accumulate substantial quantities of lipids (Sheehan et al., 1998), resulting in a high oil yield. Lipid contents of 20 to $50 \%$ of the dry biomass weight have been reported to be quite common (Spolaore et al., 2006; Li et al., 2008). It has also been reported that lipids accounting for more than $90 \%$ of the dry biomass of some microalgae have been reported in some culture conditions (Mata et al., 2010).

\section{Fatty acid composition}

Table 2 shows the fatty acid composition in $M$. pusillum harvested from different culture media. Linoleic acid (C18:2n6c) ranged from 49 to $54 \%$ of all fatty acids, and was the dominant fraction for all experimental conditions. Linoleic acid was followed by palmitic acid (C16:0) and linolenic acid (C18:3n3) ranging from 24 to $29 \%$ and 16 to $22 \%$, respectively. Oleic acid (C18:1n9c) accounted for $<5 \%$ of all fatty acids. Biodiesel quality depends on the fatty acid composition. Petkov and Garcia (2007) found 14:0, 16:0, 16:1, $18: 0,18: 1,18: 2$, and $\alpha-18: 3$ fatty acid components from green algae. A large number of double bonds in a fatty acid make it more susceptible to oxidation, thus results in economical loss (Chisti, 2007).

Nutrient composition of the growth medium, cultivation conditions, and growth phase can readily affect the fatty acid composition in algal 
Table 2. Effect of trace metals concentration in the growth medium on fatty acid composition (\%) of M. pusillum

\begin{tabular}{|c|c|c|c|c|c|c|c|c|c|c|c|}
\hline \multirow{2}{*}{ Fatty acid } & \multirow{2}{*}{ Control } & \multicolumn{2}{|c|}{ Zinc } & \multicolumn{2}{|c|}{ Cobalt } & \multicolumn{6}{|c|}{ Manganese } \\
\hline & & $\mathbf{O X}$ & $2 X$ & $0 x$ & $2 X$ & $0 x$ & $2 X$ & $3 x$ & $4 X$ & $5 X$ & $6 x$ \\
\hline Palmitic (C16:0) & $24.8 \pm 0.4$ & $25.5 \pm 0.5$ & $26.7 \pm 0.3$ & $26.4 \pm 0.5$ & $26.7 \pm 0.4$ & $25.7 \pm 0.3$ & $29.4 \pm 0.2$ & $23.9 \pm 0.6$ & $27.2 \pm 0.8$ & $24.5 \pm 0.3$ & $25.9 \pm 0.4$ \\
\hline Oleic (C18:1n9c) & $2.7 \pm 0.2$ & $2.8 \pm 0.1$ & $1.8 \pm 0.1$ & $2.4 \pm 0.2$ & $1.9 \pm 0.1$ & $2.7 \pm 0.1$ & $2.7 \pm 0.3$ & $2.2 \pm 0.1$ & $3.8 \pm 0.2$ & $2.8 \pm 0.4$ & $2.6 \pm 0.1$ \\
\hline Linoleic (C18:2n6c) & $51.9 \pm 0.8$ & $53.6 \pm 0.6$ & $53.1 \pm 0.9$ & $52.3 \pm 0.7$ & $52.5 \pm 0.9$ & $52.2 \pm 0.7$ & $52.2 \pm 1.1$ & $54.0 \pm 0.9$ & $49.8 \pm 0.5$ & $53.9 \pm 0.9$ & $50.4 \pm 0.8$ \\
\hline Linolenic (C18:3n3) & $20.6 \pm 0.4$ & $18.1 \pm 0.2$ & $18.4 \pm 0.2$ & $18.9 \pm 0.4$ & $18.9 \pm 0.3$ & $19.4 \pm 0.4$ & $15.7 \pm 0.2$ & $19.9 \pm 0.3$ & $19.2 \pm 0.3$ & $18.8 \pm 0.2$ & $21.1 \pm 0.1$ \\
\hline \multirow{2}{*}{ Fatty acid } & \multirow{2}{*}{ Control } & \multicolumn{10}{|c|}{ Copper } \\
\hline & & \multicolumn{2}{|r|}{$0 X$} & \multicolumn{2}{|c|}{$2 X$} & \multicolumn{2}{|l|}{$3 x$} & $4 X$ & \multicolumn{2}{|c|}{$5 X$} & $6 X$ \\
\hline Palmitic (C16:0) & $24.8 \pm 0.4$ & \multicolumn{2}{|c|}{$25.1 \pm 0.2$} & \multicolumn{2}{|c|}{$27.5 \pm 0.4$} & \multicolumn{2}{|l|}{$24.3 \pm 0.3$} & $26.8 \pm 0.3$ & \multicolumn{2}{|c|}{$25.9 \pm 0.6$} & $26.3 \pm 0.4$ \\
\hline Oleic (C18:1n9c) & $2.7 \pm 0.2$ & \multicolumn{2}{|c|}{$2.7 \pm 0.1$} & \multicolumn{2}{|c|}{$1.8 \pm 0.1$} & \multicolumn{2}{|l|}{$2.3 \pm 0.1$} & $4.6 \pm 0.1$ & \multicolumn{2}{|c|}{$2.7 \pm 0.2$} & $2.1 \pm 0.1$ \\
\hline Linoleic (C18:2n6c) & $51.9 \pm 0.8$ & \multicolumn{2}{|c|}{$52.6 \pm 0.6$} & \multicolumn{2}{|c|}{$52.6 \pm 0.7$} & \multicolumn{2}{|l|}{$54.1 \pm 1.1$} & $49.2 \pm 0.8$ & \multicolumn{2}{|c|}{$53.9 \pm 0.9$} & $50.0 \pm 0.7$ \\
\hline Linolenic (C18:3n3) & $20.6 \pm 0.4$ & \multicolumn{2}{|c|}{$19.6 \pm 0.2$} & \multicolumn{2}{|c|}{$18.1 \pm 0.2$} & \multicolumn{2}{|l|}{$19.3 \pm 0.4$} & $19.4 \pm 0.5$ & \multicolumn{2}{|c|}{$17.5 \pm 0.2$} & $21.6 \pm 0.5$ \\
\hline
\end{tabular}

biomass (Hu et al., 2008). Palmitic acid, oleic acid, and linoleic acid were found as the major fatty acids in both photoautotrophically and heterotrophically grown cultures of Chlorella zofingiensis (Liu et al., 2011). Of all the nutrients evaluated, nitrogen limitation is the single most critical nutrient affecting lipid metabolism in algae. A general trend towards accumulation of lipids, particularly triacylglycerols (TAG), in response to nitrogen deficiency has been observed in numerous species or strains of various algal taxa (Hu et al., 2008).

\section{Conclusion}

The present work investigated the effect of culture medium (BBM) supplemented with different concentrations of trace metals on the biomass yield, and lipid production of M. pusillum. The results demonstrate that trace metals play a major role in the algal biomass yield and lipid production. Increasing the $\mathrm{Cu}$ or $\mathrm{Mn}$ concentration in BBM increased the algal biomass and lipid productivity. BBM amended with $4 \mathrm{X}$ concentration of $\mathrm{Cu}$ or $\mathrm{Mn}$ resulted in 1.6 or 1.5 -fold increase in biomass yield and 1.4 or 1.3-fold increase in lipid productivity when compared to control, respectively.

The polyunsaturated fractions ranged from 68 to $73 \%$ of the total fatty acids (FA) in microalga cultivated under all experimental variations. The lower percentage of polyunsaturated FA was obtained from alga grown in BBM amended with $4 \mathrm{X} \mathrm{Mn}$ and $4 \mathrm{X} \mathrm{Cu}$. This study underlined the significance of medium development in achieving high-density cultures and lipid contents.

\section{ACKNOWLEDGEMENTS}

This work was supported by the Korea Institute of Energy Research, the Senior Researchers program (The National Research Foundation of Korea, 2010-0026904), the Eco-Innovation project (The Global-Top project) funded by the Korea
Ministry of Environment, and the Brain Korea-21 (BK-21) and Brain Pool (KFSTS, Grant number: 11-150-152-1600-1658) programs administrated by the Ministry of Education, Science and Technology (MEST).

\section{REFERENCES}

Abou-Shanab RAI, Hwang JH, Cho Y, Min B, Jeon BH (2011). Characterization of microalgal species isolated from fresh water bodies as a potential source for biodiesel production. Appl. Energy 88:3300-3306.

American Public Health Association (1998). Methods for biomass production. In: Standard Methods for the Examination of Water and Wastewater. American Public Health Association, Baltimore, MD, USA.

Bischoff HW, Bold HC (1963). Phycological studies IV. Some soil algae from Enchanted Rock and related algal species. University of Texas Publication 6318:1-95.

Bligh EG, Dyer WJ (1959). A rapid method of total lipid extraction and purification. Can. J. Biochem. Physiol. 37:911-917.

Campbell PK, Beer T, Batten D (2011). Life cycle assessment of biodiesel production from microalgae in ponds. Bioresour. Technol. 102:50-56.

Cheirsilp B, Torpee S (2012). Enhanced growth and lipid 
production of microalgae under mixotrophic culture condition: Effect of light intensity, glucose concentration and fed-batch cultivation. Bioresour. Technol. 110:510-516.

Chen M, Tang H, Ma H, Holland TC, Ng KYS, Salley SO (2011). Effect of nutrients on growth and lipid accumulation in the green algae Dunaliella tertiolecta. Bioresour. Technol. 102:1649-1655.

Chisti Y (2007). Biodiesel from microalgae. Biotechnol. Adv. 25:294306.

Christensen KK (1997). Differences in iron, manganese, and phosphorus binding in freshwater sediment vegetated with Littorella uniflora and benthic microalgae. Water Air Soil Pollut. 99:265-273.

Cloe"z I, Dumont O, Piciotti M, Bourre JM (1987). Alterations of lipid synthesis in the normal and dysmyelinating trembler mouse sciatic nerve by heavy metals $(\mathrm{Hg}, \mathrm{Pb}, \mathrm{Mn}, \mathrm{Cu}, \mathrm{Ni})$. Toxicology 46:65-71.

Gouveia L, Oliverira CA (2009). Micro algae as a raw material for biofuel procution. J. Ind. Microbiol. Biotechnol. 36:269-274.

Guschina IA, Harwood JL (2006). Lipids and lipid metabolism in eukaryotic algae. Prog. Lipid Res. 45:160-186.

Hosoglu MI, Gultepe I, Elibol M (2012). Optimization of carbon and nitrogen sources for biomass and lipid production by Chlorella saccharophila under heterotrophic conditions and development of Nile red fluorescence based method for quantification of its neutral lipid content. Biochem. Eng. J. 61:11-19.

Hu Q, Sommerfeld M, Jarvis E, Ghirardi M, Posewitz M, Seibert M, Darzins A (2008). Microalgal triacylglycerols as feedstocks for biofuels production: perspectives and advances. Plant J. 54:621-639.

Huang G H, Chen F, Wei D, Zhang XW, GuChen (2010). Biodiesel production by microalgal biotechnology. Appl. Energy 87:38-46.

llavarasi A, Mubarakali D, Praveenkumar R, Baldev E, Thajuddin N (2011). Optimization of various growth media to freshwater microalgae for biomass production. Biotechnology 10:540-545.

IIIman AM, Scragg AH, Shales SW (2000). Increase in Chlorella strains calorific values when grown in low nitrogen medium. Enzyme Microb. Tech. 27:631-635.

Lepage G, Roy CC (1984). Improved recovery of fatty acid through direct transesterification without prior extraction or purification. J. Lipid. Res. 25:1391-1396.

Li Y, Horsman M, Wu N, Lan CQ, Dubois-Calero N (2008). Biofuels from microalgae. Biotechnol. Prog. 24:815-820.

Liu J, Huang J, Sun Z, Zhong Y, Jiang Y, Chen F (2011). Differential lipid and fatty acid profiles of photoautotrophic and heterotrophic Chlorella zofingiensis: assessment of algal oils for biodiesel production. Bioresour. Technol. 102:106-110.

Liu ZY, Wang GC, Zhou BC (2008). Effect of iron on growth and lipid accumulation in Chlorella vulgaris. Bioresour. Technol. 99:47174722.

Lynn SG, Kilham SS, Kreeger DA, Interlandi SJ (2000). Effect of nutrient availability on the biochemical and elemental stoichiometry in freshwater diatom Stephanodiscus minutulus acillariophyceae. J. Phycol. 36:510-522.
Mata TM, Martins AA, Caetano NS (2010). Microalgae for biodiesel production and other applications: a review. Renew. Sustain. Energy Rev. 4:217-232.

Petkov G, Garcia G (2007). Which are fatty acids of the green alga Chlorella? Biochem. Syst. Ecol. 35:281-285.

Rao AR, Dayananda C, Sarada R, Shamala TR, Ravishankar GA (2007). Effect of salinity on growth of green alga Botryococcus braunii and its constituents. Bioresour. Technol. 98:560-564.

Reitan KI, Rainuzzo JR, Olsen Y (1994). Effect of nutrient limitation on fatty acid and lipid content of marine microalgae. J. Phycol. 30:972979.

Richmond A (2004). Handbook of microalgae culture: biotechnology and applied phycology. Black Well Science Ltd., Oxford, UK.

Rousch JM, Sommerfeld MR (1999). Effect of manganese and nickel on growth of selected algae in $\mathrm{pH}$ buffered medium. Water Res. 33:2448-2454.

Sheehan J, Cambreco V, Duffield J, Garboski M, Shapouri H (1998). An overview of biodiesel and petroleum diesel life cycles. A report by US Department of Agriculture and Energy 98:1-35.

Shen Y, Pei Z, Yuan W, Mao E (2009). Effect of nitrogen and extraction method on algae lipid yield. Int. J. Agric. Biol. Eng. 2:51-57.

Song L, Qin JG, Su S, Xu J, Clarke S, Shan, Y (2012). Micronutrient requirements for growth and hydrocarbon production in the oil producing green alga Botryococcus braunii (Chlorophyta). PLoS ONE 7:41459. doi:10.1371/journal.pone.0041459.

Spolaore P, Joannis-Cassan C, Duran E, Isambert A (2006). Commercial applications of Microalgae. J. Biosci. Bioeng. 101:87-96.

Wang L, Yecong L, Chen P, Min M, Chen Y, Zhu J, Ruan R (2010a). Anaerobic digested dairy manure as a nutrient supplement for cultivation of oil-rich green microalgae Chlorella sp. Bioresour. Technol. 101:2623-2628.

Wang Z, Chen S, Cao X (2010b). Micro-nutrients effects on algae colony: growth rate and biomass response to various micro-nutrients and competitive inhibitions among multi-microelements. Symp. 4th Int. Conf. Bioinformat. Biomed. Eng. pp. 1-8. 